\title{
Recovery of Cenospheres and Fine Fraction from Coal Fly Ash by a Novel Dry Separation Method
}

\author{
Jan Wrona ${ }^{1, *} \mathbb{C}$, Witold Żukowski ${ }^{2}$, Dariusz Bradło ${ }^{2}$ and Piotr Czupryński ${ }^{3}$ \\ 1 Environmental and Power Engineering, Cracow University of Technology, Warszawska 24, \\ 31-155 Cracow, Poland \\ 2 Chemical Engineering and Technology, Cracow University of Technology, Warszawska 24, \\ 31-155 Cracow, Poland; pczukows@pk.edu.pl (W.Ż.); dbradlo@pk.edu.pl (D.B.) \\ 3 PGE Energia Ciepła S.A., Ciepłownicza 1, 31-587 Cracow, Poland; Piotr.Czuprynski@gkpge.pl \\ * Correspondence: jwrona@pk.edu.pl
}

Received: 5 June 2020; Accepted: 7 July 2020; Published: 11 July 2020

check for

\begin{abstract}
Aluminosilicate microspheres are a valuable fraction of coal fly ash with diverse applications due to their low density. Currently, there is no efficient and ecologically rational method of cenosphere recovery from fly ash. A combination of dry methods for the recovery of both fine ash particles and aluminosilicate microspheres from coal fly ash is presented. It is comprised of fluidised bed separation followed by screening and pneumatic separation in a free-fall air chamber. Fluidised bed separation was assisted by a mechanical activator to prevent agglomeration. This step reduced the portion of material that required further treatment by $52-55 \mathrm{wt} . \%$, with the recovery of microspheres exceeding $97 \%$. Then, the concentrates were individually subjected to pneumatic separation. The final separation product for the fly ash containing $0.64 \mathrm{wt} . \%$ cenospheres was a cenosphere concentrate that constituted about $17 \mathrm{wt} . \%$ of the initial fly ash. The recovery of cenospheres was around $81 \%$. Usage of a combination of dry methods allowed for maintaining almost $83 \mathrm{wt} . \%$ of the raw material in its dry form. Furthermore, the produced fly ash grain fractions could be used for different industrial purposes.
\end{abstract}

Keywords: fly ash; cenospheres; fluidisation; pneumatic separation

\section{Introduction}

Nowadays, the dominant fuel used for electricity generation worldwide is coal. Energy production based on coal is inevitably connected with several issues, notably with a generation of vast amounts of combustion by-products $[1,2]$. The main coal combustion by-product is fly ash and in many countries its utilisation level is low. Fly ash is an inhomogeneous material, concerning its chemical composition and physical parameters such as density and grain size. According to the practice of sustainable waste management, the whole mass of the fly ash should be divided into fractions of different chemical and physical properties to expand potential opportunities for its use. A specific application may be found for each particular fraction and this would lead to an increase in the market value of fly ash [3]. The low density $\left(<1 \mathrm{~g} / \mathrm{cm}^{3}\right)$ aluminosilicate microspheres (MS), often called cenospheres, are an example of a valuable fraction. There are numerous applications of such material that have been recently studied e.g. cement-based composites [4], particulate reinforced metal matrix composites [5], polymer composites [6-9], a catalytic support [10-13] or a fluidised bed material [14-17]. The main reason for the applying of cenospheres in the composites is to reduce their weight and manufacturing cost, as well as to improve their properties e.g. insulation, thermal resistance or mechanical strength. Fly ash, in most cases, contains between 0.3 and $1.5 \mathrm{wt} . \%$ of aluminosilicate microspheres. To separate both materials, the difference in density between fly ash $\left(\sim 2.3 \mathrm{~g} / \mathrm{cm}^{3}\right)$ and cenospheres $\left(\sim 0.7 \mathrm{~g} / \mathrm{cm}^{3}\right)$ 
is commonly utilized [18]. Currently, there are no efficient and ecologically rational methods of cenosphere recovery from fly ash. However, both wet and dry methods are still under development.

\subsection{Microsphere Recovery Using Wet Separation Methods}

The wet methods (so-called 'sink-float' methods) are based on the collection of the top layer of the material, which is floating on the settling reservoir where the ash-slag mixture is deposited. To collect the fraction floating on the surface of the water, a system of overflow wells and a network of channels and pipes are used. Furthermore, MS concentrate is transferred to dripping chambers made of canvas in which the water content is reduced. Another approach is based on pumping out the water-ash mixture from the reservoir followed by filtration using bag separators and discharging the clean water back to the settling reservoir.

Other wet MS recovery methods are employed in laboratory settings or on a pilot scale. The recently published work by the Kiani team describes a continuous method of cenosphere recovery using an inverted reflux classifier and water as a medium. The best results were obtained using the laboratory-scale device in which $90 \mathrm{wt} . \%$ of microspheres were recovered with a product purity level of $64 \mathrm{wt} . \%$ [19]. The experiment on a pilot-scale displayed a slightly lower enrichment rate. The most successful trials showed either around $80 \mathrm{wt} . \% \mathrm{MS}$ recovery and a product containing about $17 \mathrm{wt} . \%$ MS, or recovery of $75 \mathrm{wt} . \%$ at a grade of $37 \mathrm{wt} . \%$ [20].

The main goal of implementing the flotation process is to recover the char from the fly ash. This can be seen as being an intermediate stage in the process of MS acquisition [21]. Other wet methods focus on obtaining products with different densities. The Hirajima research team [22], through the use of hydrocyclone and the multigravity separators, obtained products with densities above $2 \mathrm{~g} / \mathrm{cm}^{3}$. Moreover, the Manocha team [23] compared the microsphere content in the fly ash using water or acetone. The content was $0.7 \mathrm{wt} . \% \mathrm{MS}$ in water and $0.8 \mathrm{wt} . \%$ cenospheres in acetone. This was explained by the authors as a result of the pozzolanic properties of fly ash in water. Recently, Yoriya et al. [24], in their work, performed the separation of cenospheres from lignite fly ash using acetone-water mixture.

The application of wet methods for MS recovery is limited to thermal power plants, which discharge waste slurry into settling reservoirs. Fly ash can be mostly utilised (e.g. in the construction industry) in its dry form. However, the water separation process results in the deterioration of its properties like self-cementation [24,25]. What is more, the remaining sediment, which constitutes around $99 \mathrm{wt} . \%$ of the initial fly-ash amount, needs to be dried before utilisation. The storage of the coal combustion by-products in the settling reservoirs requires a large area and may lead to the contamination of water and soil by the heavy metals contained in fly ash. For these reasons, more effort is being made to create an effective dry method for the recovery of microspheres.

\subsection{Microsphere Recovery Using Dry Separation Methods}

The alternative to wet methods of MS recovery are dry separation processes. Some of the researchers [26] defined cenospheres as particles with a density lower than those of fly ash, but greater than $1 \mathrm{~g} / \mathrm{cm}^{3}$. Therefore, the results of their studies cannot be compared with other papers. The Zyryanov team [27] implemented a combination of four devices: an electro-mass-classifier, a magnetic separator, a triboadhesion separator and an electrostatic separator. As a result, they achieved four fly ash fractions; among these was a coarse by-product with a MS content of around $2-4 \mathrm{wt} . \%$ and MS recovery of around $30 \%$.

Significantly better results than those achieved by Zyryanov et al. were achieved by Hirajima [28] using a micron separator built by Hosokawa Co. The effectiveness of the fly ash and microsphere mixture separation was tested using a feed with a flow rate of $170 \mathrm{~kg} / \mathrm{h}$ and containing $20 \mathrm{wt} . \%$ MS. It was determined that the ideal conditions enabled a $66 \%$ MS recovery and that the product represented around $30 \mathrm{wt} . \%$ of the input. Further research conducted by the same team [29] compared the micron separator with the pneumatic separator $(100 \mathrm{~g} / \mathrm{min}$ feed). The pneumatic separator usage 
had lower efficiency than the micron separator as the maximum MS recovery was $63 \%$ with the product constituting around $45 \mathrm{wt} . \%$ of the input. The same paper showed separation results of fly ash with an initial MS content of $0.28 \mathrm{wt} . \%$. The separation concentrate, representing merely $12.2 \mathrm{wt} . \%$ of the initial fly ash, contained $1.72 \mathrm{wt} . \%$ cenospheres (75\% MS recovery). Although the presented method required additional water separation, the portion of fly ash that requires wet processing was reduced by $87.8 \mathrm{wt} . \%$.

Another approach is presented in Ramme and co-workers' patent [30], in which a fluidising vertical column for the separation of microspheres was used. The inventors conducted the initial trials by the centrifuge air separator. They observed that single-stage separation by density or by particle diameter would be ineffective due to similar densities and sizes of the two types of particles as well as their tendency to agglomeration. The authors proposed applying grain separation as the first step followed by fluidised bed (FB) separation. In the given example, fly ash with a microsphere content of $0.6 \mathrm{wt} . \%$ was divided using a $38 \mu \mathrm{m}$ mesh size sieve. A fraction $>38 \mu \mathrm{m}$ (containing $1 \mathrm{wt} . \% \mathrm{MS}$ ) was subjected to FB separation. The product contained $5.4 \mathrm{wt} . \% \mathrm{MS}$ and constituted around $2.0 \mathrm{wt} . \%$ input. Therefore, the recovery of the cenospheres was $18 \%$.

Calculations of Newton's efficiency have been performed for the evaluation of the dry methods [31]:

$$
\begin{gathered}
\eta=R_{C}+R_{F A}-1, \\
R_{C}=\frac{c_{p} \cdot x_{p}}{c_{f}}, \\
R_{F A}=1-\frac{\left(1-c_{p}\right) \cdot x_{p}}{\left(1-c_{f}\right)} .
\end{gathered}
$$

Thus, Newton's efficiency can be presented as:

$$
\eta=\frac{x_{p} \cdot\left(c_{p}-c_{f}\right)}{c_{f} \cdot\left(1-c_{f}\right)} .
$$

Newton's efficiency expressed in Equation (4) always has positive values when the microsphere content in the product is higher than in the raw material, which is a necessary condition for an effective MS recovery process.

Because of the many disadvantages of wet separation, some extensive studies are currently being performed to develop the most effective ways of MS dry recovery. These methods are the subject of several patents. However, their efficiency and the costs involved make them difficult to implement on a large scale. Using fluidisation is effective, but the microsphere content in the product seems to indicate that an additional separation step is needed and should most likely be based on a dry method.

There are numerous known air classification devices. The choice of its type depends on properties of the separated materials [32]. Fluidised bed classifiers could be applied to the cenospheres' recovery from fly ash. The main issue with the fluidisation of fly ash is the formation of agglomerates of fine particles due to adhesion. There are various methods to enhance the fluidisation of ultrafine particles, among them the addition of foreign particles [33]. The currently applied technique proposed by Ramme et al. [30], that makes it possible to effectively fluidise the fly ash, is connected with the dry sieving of fly ash below $38 \mu \mathrm{m}$, which is highly ineffective. Other popular devices that could be used for the division of the classified material into two fractions are centrifugal air classifiers (like the rotor classifier $[28,34]$ or circulating air classifier $[35,36])$. However, for the cenospheres' recovery from fly ash, it would be more favourable to obtain a series of fractions due to the possibility of overlapping fine fly ash particles with larger and lighter cenospheres. An example of such a device is the gravitational-crossflow zone classifier, which has already proved its performance in the simulated recovery of cenospheres using 1:1 fly ash-cenospheres mixture [37]. 
This article presents research on the recovery of aluminosilicate microspheres from fly ash using an original multistage physical method. The proposed fly ash separation method consists of the following stages:

- FB separation — fine fraction separation using a fluidised bed with a mechanical activator;

- screening - ash concentrate division into grain fractions;

- pneumatic separation-grain fraction classification;

- MS collecting-MS recovery using a wet method (sink-float).

The process of FB separation with a mechanical activator could potentially improve fluidisation of fly ash as well as allow the retrieval of the fine fraction from fly ash. Further pneumatic classification could facilitate the selective fraction collection. In this manner, the efficiency of cenosphere recovery and product grade could be improved. What is more, the amount of material subjected to further wet separation should be significantly reduced. The pneumatic separator with a series of receivers, and its performance in cenosphere recovery, should be tested in laboratory conditions using the typical fly ash input.

\section{Materials and Methods}

The raw material for the research came from a power plant in Poland employing steam boilers (OP-650 type, max. continuous feed rate: $182 \mathrm{~kg} / \mathrm{s}$, bituminous coal, Rafako, PBG Group, Poland), which were supplied with powdered coal. The fly ash was separated by electrostatic precipitators and then transferred to three hoppers. The test samples were retrieved from the first and the second hopper at two intervals. Thus, four samples were collected. Three of these samples $\left(\mathrm{FA}_{1}, \mathrm{FA}_{2}, \mathrm{FA}_{3}\right)$ were subjected to analysis and had cenosphere contents of $0.64 \mathrm{wt} . \%, 0.49 \mathrm{wt} \%$ and $0.38 \mathrm{wt} . \%$, respectively. The fourth sample, with the lowest cenosphere content (below $0.2 \mathrm{wt} . \%$ ), was rejected.

\subsection{Fluidised Bed Separation}

The main goal of this stage was to isolate the finest fly ash particles to minimise the mass of the material being processed in subsequent stages. A laboratory fluidised-bed reactor with a quartz tube measuring $500 \mathrm{~mm}$ in length and $100 \mathrm{~mm}$ in diameter was used. The reactor was supplied with $250 \mathrm{~g}$ of quartz sand with particle sizes of 300-385 $\mu \mathrm{m}$. The sand acted as a fluidised bed before adding the fly ash. Afterwards, the sand particles facilitated the separation of the smallest particles by colliding with the fly ash agglomerates. The mutual collisions between the large sand particles and the agglomerate ash particles impaired the weak intermolecular interactions. Thus, the sand acted primarily as a mechanical activator in the FB separation process. The fluidisation was maintained with an airflow of $1.5 \mathrm{dm}^{3} / \mathrm{s}$ at ambient temperature and atmospheric pressure. The fly ash was gradually added at suitable time intervals in ten doses of $100 \mathrm{~g}$ each. Simultaneously, the pressure loss was measured using the MPX 2010 DP differential pressure sensor to ensure fine fraction separation. The fly ash particles that were evacuated with air out of the reactor, were collected in the sediment chamber and the cyclone (Figure 1). All the products from the FB separation were collected and the sand was subsequently removed by sieving it through a $250 \mu \mathrm{m}$ mesh sieve. The material used in the next separation step was a fraction below $250 \mu \mathrm{m}$ that was designated as a fluidised bed concentrate (FBC).

\subsection{Screening of the Fluidised Bed Concentrate}

The sieving analysis of the FBCs was conducted using a set of sieves of mesh sizes: 71, 100, 125, 160 and $200 \mu \mathrm{m}$. Two parallel measurements were carried out, these used about $100 \mathrm{~g}$ of the material and rubber elements to prevent agglomeration. The aim of dividing the material into grain fractions before the pneumatic separation was the homogenisation of the material to apply distinct conditions for each narrow grain fraction. As a result, the FBCs were divided into three grain fractions (A, B, C). These were subsequently subjected to pneumatic separation. The sieving analysis and further screening were performed in the dry form to eliminate the interaction of the fly ash with water. 


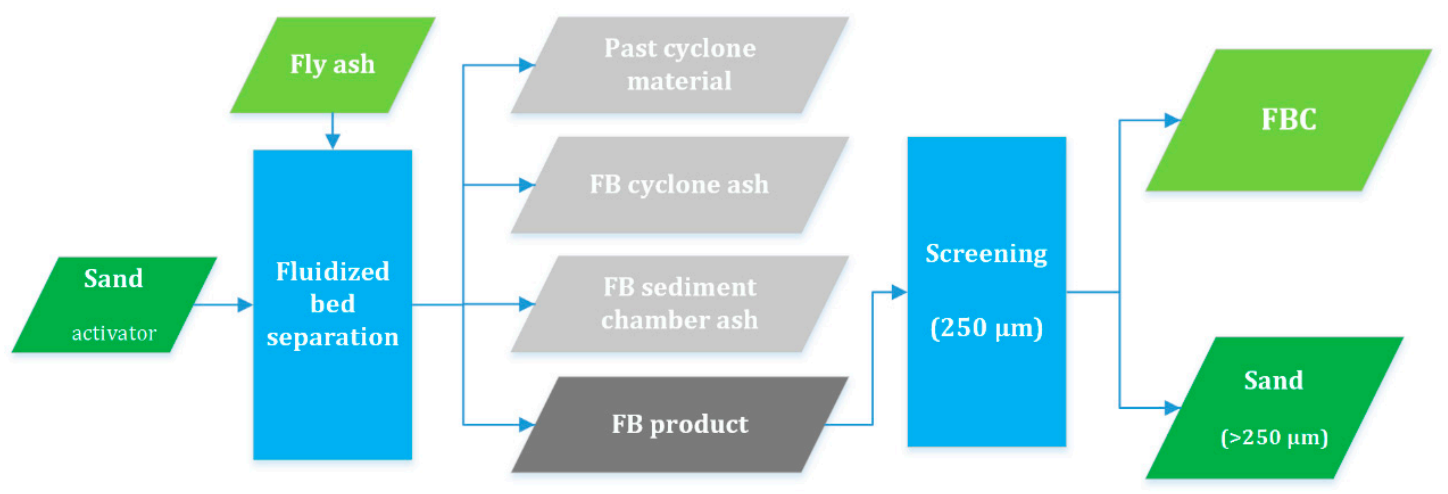

Figure 1. Fluidised bed (FB) separation scheme.

\subsection{Pneumatic Separation}

The pneumatic separation was conducted in a specially designed device (Figure 2). The dimensions of the free-fall air chamber were $400 \times 100 \times 350 \mathrm{~mm}$ (length $\mathrm{x}$ width $\mathrm{x}$ height). The device enables partitioning of the feed into fifteen fractions, which further improves the selectivity of the microsphere recovery. The airflow in the air chamber of the separator was forced by a vacuum controlled by the TSI 40241 mass flowmeter. During the experiment, the outer air flow was monitored by the Lutron AM-4204 hot-wire anemometer. To ensure uniform flow throughout the entire chamber, a laminar system was adopted at both the entrance and the exit of the separating chamber. The FBCs were dosed into the chamber using the plate feeder at a dosing rate of 2,6 and $3 \mathrm{~g} / \mathrm{min}$ for the $\mathrm{FA}_{1}, \mathrm{FA}_{2}$ and $\mathrm{FA}_{3}$, respectively. Different flow rates were applied to evaluate its influence on the separation efficiency. The fly ashes $\mathrm{FA}_{1}$ and $\mathrm{FA}_{2}$ were similar in terms of granulation, hence a triple increase in feed rate would substantially increase the overall yield from the apparatus volume. The air flow rates were approximately $140 \mathrm{dm}^{3} / \mathrm{min}, 200 \mathrm{dm}^{3} / \mathrm{min}$ and $300 \mathrm{dm}^{3} / \mathrm{min}$ for the fine (C), medium-grained (B) and coarse fractions (A), respectively. Its values were adjusted for each granular fraction in the manner that no material was located neither before nor past the receiver.

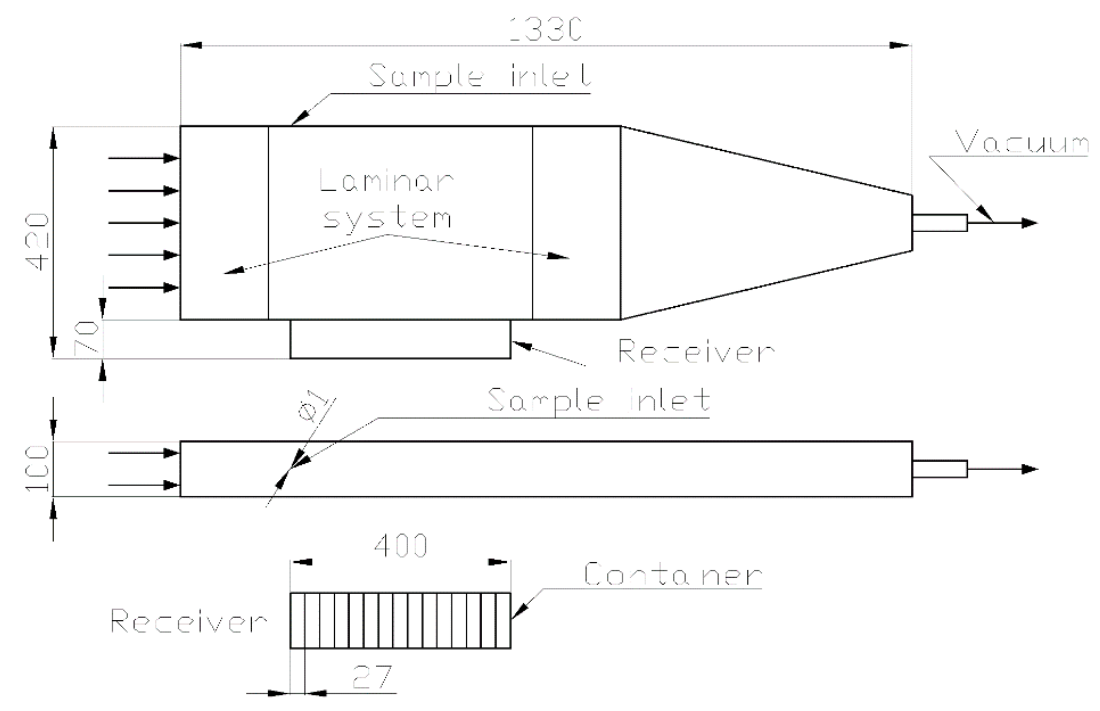

Figure 2. Pneumatic separator outline.

\subsection{Microsphere Content Determination}

The raw microspheres (part of the fly ash floating on the surface of the water) contain both the microspheres and the unburnt coal (char) particles. To separate these particles, the calcination process was performed in the muffle furnace at $600^{\circ} \mathrm{C}$ for $2 \mathrm{~h}$. Afterwards, the MS content in the sample was 
measured by the sink-float method followed by filtration and drying at $105^{\circ} \mathrm{C}$ for $12 \mathrm{~h}$. Analyses were conducted for materials from the sediment chamber and the cyclone as well as for fractions after pneumatic separation. The receiver was divided into fifteen containers. However, the experiments showed that fractions accumulate in a non-uniform manner in the receiver and some fractions weighed less than $1 \mathrm{~g}$. Therefore, to eliminate analytical errors the product of separation was divided into four final parts (I-IV). The combination criteria were the minimum mass of a part $(2 \mathrm{~g})$ and maintaining the decreasing tendency of the mass of the following parts.

\section{Results and Discussion}

Figure 3 presents the results of the first stage of MS recovery using the fluidised bed reactor. It is clearly shown that the bed, during the process, underwent segregation into characteristic layers: the bottom layer included mostly sand particles, the middle layer consisted of coarse fly ash particles and the upper layer contained in the majority char particles. Hence, there are also alternative ways of retrieving the products from the reactor e.g. layer by layer or continuous separation. Fractions obtained in this manner do not need to be subjected to laborious division into grain fractions, directly isolating the activator from the remaining products.

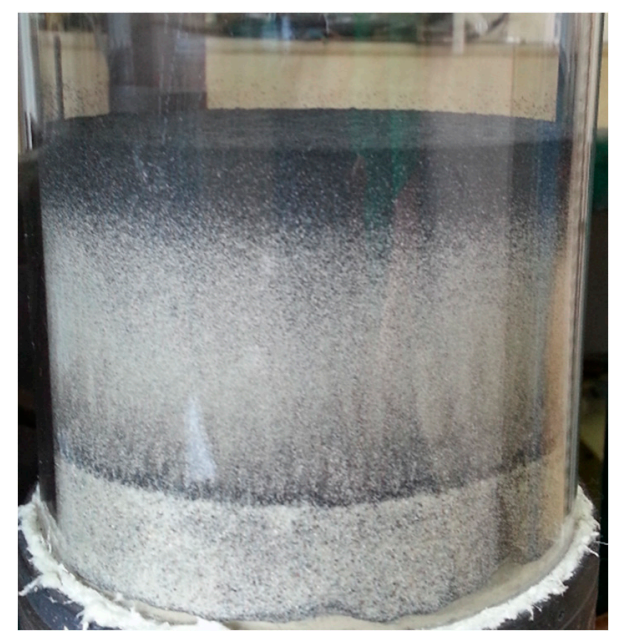

Figure 3. Results of FB separation.

The mass balance of the process (Table 1) indicates a significant reduction in the fly ash mass during the FB separation because the FBC represents $45-48 \mathrm{wt} . \%$ of the initial fly ash. Therefore, the need for further physical processing is reduced by more than half. Fly ashes from the first hopper $\left(\mathrm{FA}_{1}\right.$ and $\left.\mathrm{FA}_{2}\right)$ possess a similar $\mathrm{FBC}$ share, while the finer $\mathrm{FA}_{3}$ yielded a lower share of the coarse fraction. The majority of the fine fly ash was collected in the sediment chamber and the cyclone. The material that was identified as 'past cyclone material' was the finest particles not captured by the cyclone and the residue deposited on the apparatus walls. This was specific to the laboratory set up and did not influence the experiment results. All three types of fine fractions, in summary, shared $51-54 \mathrm{wt} . \%$ of the initial fly ash and after this stage of the recovery process could be collectively or individually directed to specific applications. Furthermore, all types of fine fly ash fractions could be treated as valuable material with the low value of fineness (category $S$ according to EN 450-1). Fine fly ash particles proved their superiority in terms of improving the compressive strength of cementitious composites [38]. Thus, the retrieved fine fraction could be used to produce high-strength concretes.

Based on the FBCs sieve analysis results, two sieves were selected with $71 \mu \mathrm{m}$ and $125 \mu \mathrm{m}$ mesh sizes to obtain three fractions with a similar mass share from each concentrate (Table 2). These fractions were: $\mathrm{A}(125-250 \mu \mathrm{m}), \mathrm{B}(71-125 \mu \mathrm{m}), \mathrm{C}(<71 \mu \mathrm{m})$. $\mathrm{FBC}_{1}$ and $\mathrm{FBC}_{2}$ had similar granulation and both were coarser than $\mathrm{FBC}_{3}$, which consisted of around $48 \mathrm{wt} . \%$ of particles below $71 \mu \mathrm{m}$. 
Table 1. FB separation mass balance, $\mathrm{g}$.

\begin{tabular}{ccccc}
\hline Type & Type of Material & $\mathbf{F A}_{\mathbf{1}}$ & $\mathbf{F A}_{\mathbf{2}}$ & $\mathbf{F A}_{\mathbf{3}}$ \\
\hline input-raw material & fly ash & 1000.0 & 1000.0 & 1000.0 \\
input-activator & sand & 250.0 & 250.0 & 250.0 \\
\hline output-fine fraction & FB sediment chamber ash & 245.8 & 254.8 & 207.4 \\
output-fine fraction & FB cyclone ash & 135.8 & 192.5 & 194.4 \\
output-coarse fraction & FBC & 482.6 & 472.2 & 452.7 \\
output-activator & sand $>250 \mu \mathrm{m})$ & 255.8 & 247.8 & 254.3 \\
output-fine fraction & past cyclone material & 130.0 & 82.7 & 141.2 \\
\hline
\end{tabular}

Table 2. Share of grain fractions in FBCs-sieve analysis results, wt.\%.

\begin{tabular}{cccc}
\hline Fraction Designation, (diameter, $\boldsymbol{\mu m})$ & $\mathbf{F B C}_{\mathbf{1}}$ & $\mathbf{F B C}_{\mathbf{2}}$ & $\mathbf{F B C}_{\mathbf{3}}$ \\
\hline $\mathrm{A},(125-250)$ & 24.6 & 23.0 & 17.1 \\
$\mathrm{~B},(71-125)$ & 36.6 & 38.6 & 35.0 \\
C, $(<71)$ & 38.8 & 38.4 & 47.9 \\
\hline
\end{tabular}

The obtained nine materials were subjected to pneumatic separation and were afterwards combined to form four final parts (I-IV). These parts subsequently underwent wet processing to acquire microspheres. The results of the MS content determination in the materials are presented in Tables 3-5.

Fluidised bed separation led to a slight concentration of aluminosilicate microspheres. FBCs contained 1.3 wt. $\%, 1.0$ wt. $\%$ and 0.8 wt. $\%$ of cenospheres with 0.5 wt. $\%, 0.6$ wt. $\%$ and 0.3 wt. $\%$ of floating unburnt carbon for $\mathrm{FBC}_{1}, \mathrm{FBC}_{2}$ and $\mathrm{FBC}_{3}$, respectively. Cenospheres were located mainly in the coarse fractions (A), which contained $53 \%, 60 \%$ and $44 \%$ of total cenospheres amount in $\mathrm{FA}_{1}$, $\mathrm{FA}_{2}$ and $\mathrm{FA}_{3}$, respectively. Fine fractions (C) exhibited only about $6 \%$ share of total cenospheres amount in $\mathrm{FA}_{1}$ and $\mathrm{FA}_{2}$ and $10 \%$ in $\mathrm{FA}_{3}$. This means that simple screening on 71 sieves would provide substantial mass reduction with an acceptable lowering of cenospheres recovery. Nevertheless, the process of pneumatic classification could be an advantageous microsphere concentration method. It facilitates selective fraction collection through the implementation of the receiver consisting of several independent containers.

The raw microspheres obtained from all parts of the FBCs contained a considerable proportion of floating unburnt coal particles (up to $84 \mathrm{wt} . \%$ ). These were mostly located in parts A, and to a lesser extent, in B. Simultaneously, parts A of FBCs were rich in MS, while parts C contained only up to around $1 \mathrm{wt} . \%$ MS. Parts A II and B II of $\mathrm{FBC}_{1}$ were the most abundant in MS with contents of $5.83 \mathrm{wt} . \%$ and $5.08 \mathrm{wt} . \%$, respectively. In general, cenospheres and floating unburnt carbon contents were positively correlated, which means that its apparent densities are similar. Separation of these materials is challenging, but the thermal method (calcination) was successfully applied to burnout residual carbon.

The by-products of the FB separation-the sediment chamber ash and the cyclone ash-both contained less than $0.1 \mathrm{wt} . \%$ of the MS content in the FA. This means that as high as $98 \%$ MS recovery was achieved during the FB process. The process of FB separation using a fluidised bed with a mechanical activator significantly reduces the amount of material subjected to further separation with minimal and negligible microsphere fraction loss.

Newton's efficiency (Equation (4)) had a positive value in reference to selected products of pneumatic separation, showing a MS content greater than that found in the FBCs (Tables 3-5). It is clearly shown in Figure 4, where only some FBCs parts have a MS content (green dots) higher than in the initial $\mathrm{FBCs}$ (red line). Grain fractions of $\mathrm{FBC}_{2}$ and $\mathrm{FBC}_{3}$ had similar distributions of floating unburnt carbon and MS: fractions A had the maximum MS contents in fractions located around 8-10 $\mathrm{cm}$ from the entry of the receiver, while the highest char contents were obtained for the last (IV) parts. In fractions $B$ and $C$, contents of MS and char were correlated and similar in value. $\mathrm{FBC}_{1}$ is characterized by different distributions of unburnt carbon and MS (except for the fraction C). The reason for that 
were higher MS content, lower char content and different partitions of the fractions into final parts in comparison to the $\mathrm{FBC}_{2}$ and $\mathrm{FBC}_{3}$.

Table 3. The aluminosilicate microspheres (MS) content in the fly ash $\mathrm{FA}_{1}$ fractions.

\begin{tabular}{|c|c|c|c|c|c|c|c|}
\hline Fraction & $\begin{array}{c}\text { Raw MS } \\
\text { Content, } \\
\text { wt. } \%\end{array}$ & $\begin{array}{l}\text { Char } \\
\text { Content, } \\
\text { wt. } \%\end{array}$ & $\begin{array}{c}\text { MS } \\
\text { Content, } \\
\text { wt. } \%\end{array}$ & $\begin{array}{c}\text { MS Content } \\
\text { in the FA, } \\
\text { wt. } \%\end{array}$ & $\begin{array}{c}\text { MS Content } \\
\text { in the FBC, } \\
\text { wt. } \%\end{array}$ & $\mathrm{R}_{\mathrm{C}}, \%$ & $\eta, \%$ \\
\hline A I & 3.47 & 1.35 & 2.13 & 0.21 & 0.44 & 33.6 & 13.3 \\
\hline A II & 18.07 & 12.24 & 5.83 & 0.10 & 0.21 & 15.9 & 12.5 \\
\hline A III & 17.59 & 14.73 & 2.86 & 0.02 & 0.03 & 2.5 & 1.4 \\
\hline A IV & 2.02 & 1.01 & 1.01 & 0.00 & 0.01 & 0.5 & -0.1 \\
\hline B I & 1.19 & 0.64 & 0.55 & 0.07 & 0.14 & 11.2 & -15.6 \\
\hline B II & 5.40 & 0.32 & 5.08 & 0.16 & 0.33 & 25.6 & 19.3 \\
\hline B III & 2.81 & 0.38 & 2.43 & 0.02 & 0.03 & 2.7 & 1.3 \\
\hline B IV & 3.12 & 0.69 & 2.43 & 0.01 & 0.03 & 2.2 & 1.0 \\
\hline C I & 0.13 & 0.03 & 0.11 & 0.01 & 0.03 & 2.2 & -25.3 \\
\hline C II & 0.36 & 0.10 & 0.26 & 0.01 & 0.02 & 1.7 & -6.9 \\
\hline C III & 1.08 & 0.38 & 0.70 & 0.01 & 0.01 & 0.9 & -0.7 \\
\hline C IV & 1.11 & 0.06 & 1.05 & 0.01 & 0.01 & 1.0 & -0.2 \\
\hline Sediment chamber & 0.05 & 0.01 & 0.04 & 0.01 & & & \\
\hline Cyclone & 0.03 & 0.01 & 0.02 & 0.003 & & & \\
\hline Sum & & & & 0.64 & 1.30 & & \\
\hline
\end{tabular}

Table 4. The MS content in the fly ash $\mathrm{FA}_{2}$ fractions.

\begin{tabular}{|c|c|c|c|c|c|c|c|}
\hline Fraction & $\begin{array}{c}\text { Raw MS } \\
\text { Content, } \\
\text { wt. } \%\end{array}$ & $\begin{array}{l}\text { Char } \\
\text { Content, } \\
\text { wt. } \%\end{array}$ & $\begin{array}{c}\text { MS } \\
\text { Content, } \\
\text { wt. } \%\end{array}$ & $\begin{array}{c}\text { MS Content } \\
\text { in the FA, } \\
\text { wt. } \%\end{array}$ & $\begin{array}{c}\text { MS Content } \\
\text { in the FBC, } \\
\text { wt. } \%\end{array}$ & $\mathrm{R}_{\mathrm{C}}, \%$ & $\eta, \%$ \\
\hline A I & 1.19 & 0.28 & 0.91 & 0.07 & 0.14 & 13.7 & -1.6 \\
\hline A II & 7.09 & 3.89 & 3.20 & 0.16 & 0.34 & 33.3 & 23.0 \\
\hline A III & 11.94 & 8.36 & 3.58 & 0.05 & 0.10 & 10.3 & 7.5 \\
\hline A IV & 12.15 & 9.23 & 2.93 & 0.01 & 0.03 & 2.6 & 1.7 \\
\hline B I & 0.82 & 0.41 & 0.41 & 0.05 & 0.10 & 9.9 & -14.8 \\
\hline B II & 2.14 & 1.03 & 1.11 & 0.07 & 0.15 & 14.8 & 1.3 \\
\hline B III & 2.79 & 1.32 & 1.47 & 0.02 & 0.05 & 5.0 & 1.6 \\
\hline B IV & 3.62 & 1.96 & 1.66 & 0.02 & 0.05 & 4.6 & 1.8 \\
\hline C I & 0.13 & 0.03 & 0.10 & 0.01 & 0.02 & 1.9 & -17.1 \\
\hline C II & 0.56 & 0.14 & 0.42 & 0.01 & 0.01 & 1.4 & -2.1 \\
\hline C III & 0.81 & 0.24 & 0.58 & 0.01 & 0.01 & 1.3 & -1.0 \\
\hline C IV & 1.47 & 0.60 & 0.87 & 0.01 & 0.01 & 1.2 & -0.2 \\
\hline Sediment chamber & 0.06 & 0.02 & 0.04 & 0.01 & & & \\
\hline Cyclone & 0.03 & 0.01 & 0.02 & 0.004 & & & \\
\hline Sum & & & & 0.49 & 1.01 & & \\
\hline
\end{tabular}

Figure 4 also provides information about the mass share of fractions collected in the receiver and the way of grouping them into parts. Pneumatic separation of FBC fractions was performed using a feed rate of $2 \mathrm{~g} / \mathrm{min}$ for $\mathrm{FBB}_{1}$ and $6 \mathrm{~g} / \mathrm{min}$ for $\mathrm{FBC}_{2}$. The increase in feed rate for $\mathrm{FBC}_{2}$ fractions led to an unfavourable outcome. The first part in coarse fraction (A I) was characterized by the negative value of Newton's efficiency with relatively high (14\%) cenosphere recovery (Table 4$)$. Thus, rejecting of this fraction from further processing led to a significant reduction in the total recovery. Similar issues were observed for the first part of medium grain fraction (B I) for all FBCs. The explanation of these outcomes could be a high share of collected material in one or two containers of the receiver, rather than its broad distribution like for fraction $\mathrm{A}$ of $\mathrm{FBC}_{1}$. This is one of the main drawbacks of using the 
pneumatic separator, which could probably be limited by the increase in air flow rate and allowing the evacuation of some of the material out of the apparatus. In this way, material distribution would be broader and at the same time it would be possible to enhance the overall yield by an increase in feed rate. In such a solution, part of the material would be located outside of the receiver and it would cause losses of about $5 \%$ of cenospheres, which is acceptable.

Table 5. The MS content in the fly ash $\mathrm{FA}_{3}$ fractions.

\begin{tabular}{|c|c|c|c|c|c|c|c|}
\hline Fraction & $\begin{array}{c}\text { Raw MS } \\
\text { Content, } \\
\text { wt. } \%\end{array}$ & $\begin{array}{c}\text { Char } \\
\text { Content, } \\
\text { wt. } \%\end{array}$ & $\begin{array}{c}\text { MS } \\
\text { Content, } \\
\text { wt. } \%\end{array}$ & $\begin{array}{c}\text { MS Content } \\
\text { in the FA, } \\
\text { wt. } \%\end{array}$ & $\begin{array}{c}\text { MS Content } \\
\text { in the FBC, } \\
\text { wt. } \%\end{array}$ & $\mathrm{R}_{\mathrm{C}}, \%$ & $\eta, \%$ \\
\hline A I & 0.99 & 0.05 & 0.94 & 0.06 & 0.13 & 16.6 & 2.2 \\
\hline A II & 8.66 & 3.81 & 4.85 & 0.07 & 0.16 & 19.3 & 16.2 \\
\hline A III & 12.81 & 8.73 & 4.08 & 0.02 & 0.05 & 6.0 & 4.8 \\
\hline A IV & 11.12 & 9.30 & 1.81 & 0.01 & 0.02 & 2.3 & 1.3 \\
\hline B I & 1.02 & 0.35 & 0.67 & 0.07 & 0.16 & 19.1 & -4.0 \\
\hline B II & 2.74 & 1.09 & 1.65 & 0.06 & 0.14 & 17.6 & 9.0 \\
\hline B III & 4.43 & 1.83 & 2.60 & 0.02 & 0.04 & 5.0 & 3.5 \\
\hline B IV & 8.45 & 4.70 & 3.75 & 0.01 & 0.03 & 3.6 & 2.9 \\
\hline C I & 0.14 & 0.02 & 0.12 & 0.02 & 0.03 & 4.3 & -25.0 \\
\hline C II & 0.27 & 0.03 & 0.24 & 0.01 & 0.03 & 3.6 & -8.5 \\
\hline C III & 0.44 & 0.07 & 0.37 & 0.004 & 0.01 & 1.2 & -1.4 \\
\hline C IV & 0.59 & 0.14 & 0.44 & 0.01 & 0.01 & 1.4 & -1.1 \\
\hline Sediment chamber & 0.07 & 0.02 & 0.05 & 0.01 & & & \\
\hline Cyclone & 0.02 & 0.01 & 0.01 & 0.003 & & & \\
\hline Sum & & & & 0.38 & 0.81 & & \\
\hline
\end{tabular}
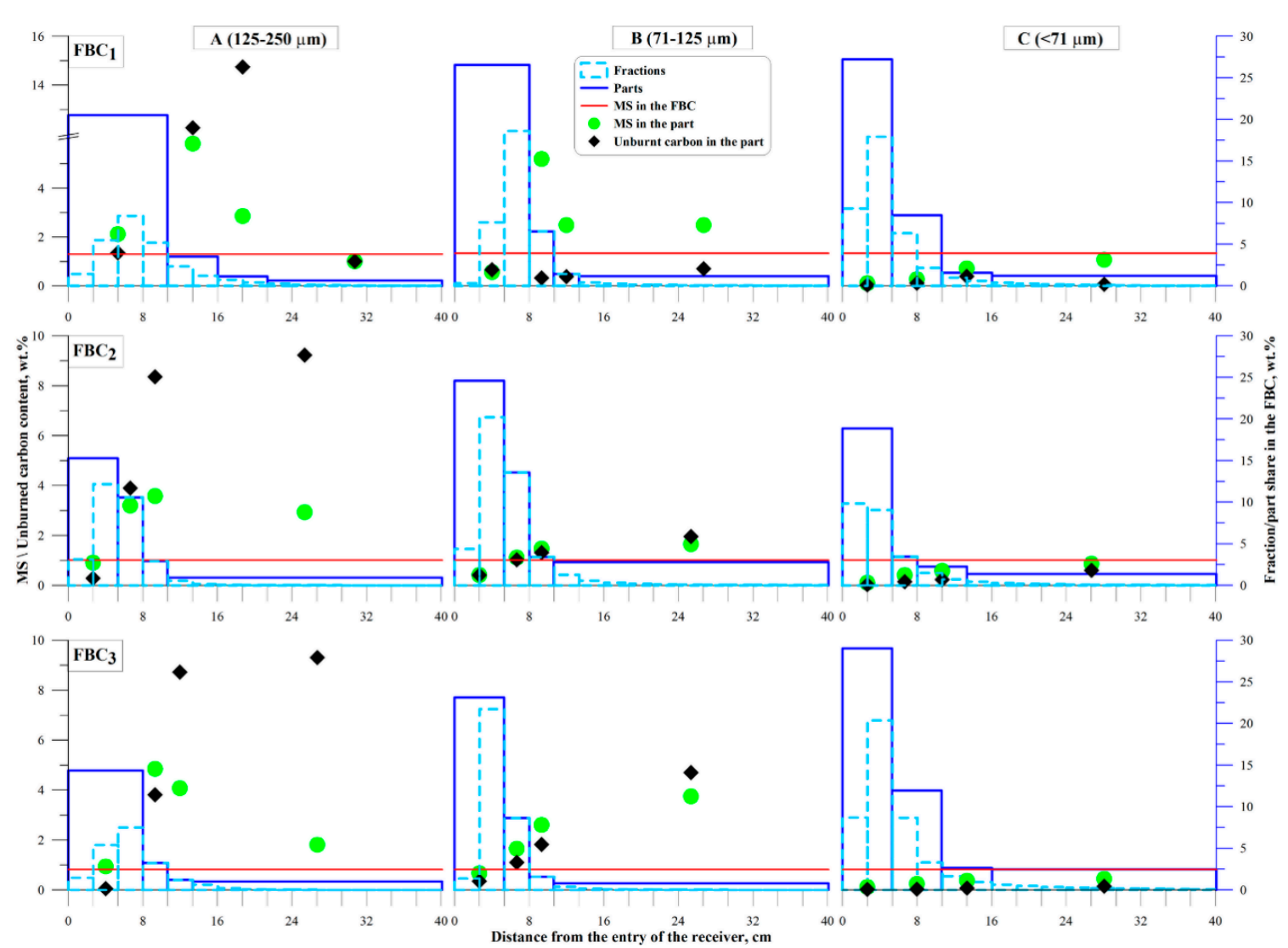

Figure 4. Fluidised bed concentrates (FBCs) pneumatic separation summary. 
Choice of Optimal Separation Variant for MS Recovery

Based on the presented results, it was possible to perform further calculations to choose the manner of combining the parts of the FBCs to attain a maximum efficiency of MS recovery. The proposed experimental set up enables the selection of the different fraction combinations. The criterion for a positive Newton's efficiency value was met by six concentrate fractions of $\mathrm{FBC}_{1}$ and $\mathrm{FBC}_{2}$ as well as by seven fractions of $\mathrm{FBC}_{3}$.

Six variants of MS recovery were compared for each fly ash type (Table 6). Additionally, values of Rc times $\eta$ were calculated to emphasise the fact that high values for both parameters were the requirements for effective MS recovery. The first variant, chosen for the purpose of comparison, only involved the screening of the FBCs $(71 \mu \mathrm{m}$ sieve) and excluded the application of the pneumatic separator. This variant was comparable with the variant where the pneumatic separator was used in the case of $\mathrm{FBC}_{3}$, containing the lowest amount of cenospheres. In this trial, pneumatic separation led to an increase in Newton's efficiency, but the cenospheres recovery was lowered compared to screening. The reason for that were the aforementioned issues with not optimal arrangement of the pneumatic separator. The best variant of MS recovery in terms of Newton's efficiency proved to be the variant adopting all parts of the FBCs with positive values of Newton's efficiency.

Table 6. Different variants of the MS recovery dry method.

\begin{tabular}{|c|c|c|c|c|c|c|c|c|c|}
\hline Fly Ash & Fraction & $\begin{array}{l}\text { Number } \\
\text { of Parts }\end{array}$ & $\begin{array}{c}\text { Share in } \\
\text { the FA, } \\
\text { wt. } \%\end{array}$ & $\begin{array}{c}\text { Share in } \\
\text { the FBC, } \\
\text { wt. } \%\end{array}$ & $\begin{array}{c}\text { MS } \\
\text { Content, } \\
\text { wt. } \%\end{array}$ & $\begin{array}{c}\text { Char } \\
\text { Content, } \\
\text { wt. } \%\end{array}$ & $\mathbf{R}_{\mathrm{C}}, \%$ & $\eta, \%$ & $\mathbf{R}_{C} \cdot \eta, \%$ \\
\hline \multirow{7}{*}{$\mathrm{FA}_{1}$} & $\mathrm{FBC}_{1}$ & 12 & 48.3 & 100.0 & 1.3 & 1.1 & 100 & 0 & 0 \\
\hline & $>71 \mu \mathrm{m} \mathrm{FBC}_{1}$ & 8 & 29.7 & 61.5 & 2.0 & 1.8 & 94 & 33 & 31 \\
\hline & A I-III, B II-IV & 6 & 16.6 & 34.3 & 3.1 & 2.7 & 83 & 49 & 40 \\
\hline & A I-II, B II & 3 & 14.8 & 30.6 & 3.2 & 2.4 & 75 & 45 & 34 \\
\hline & A I, B II & 2 & 13.0 & 27.0 & 2.8 & 1.1 & 59 & 33 & 19 \\
\hline & A I & 1 & 9.9 & 20.5 & 2.1 & 1.3 & 34 & 13 & 4 \\
\hline & B II & 1 & 3.2 & 6.5 & 5.1 & 0.3 & 26 & 19 & 5 \\
\hline \multirow{7}{*}{$\mathrm{FA}_{2}$} & $\mathrm{FBC}_{2}$ & 12 & 47.2 & 100.0 & 1.0 & 1.1 & 100 & 0 & 0 \\
\hline & $>71 \mu \mathrm{m} \mathrm{FBC}_{2}$ & 8 & 35.0 & 74.0 & 1.3 & 1.5 & 94 & 20 & 19 \\
\hline & A II-IV, B II-IV & 6 & 16.1 & 34.2 & 2.1 & 2.9 & 71 & 37 & 26 \\
\hline & A II-III, B II & 3 & 12.8 & 27.1 & 2.2 & 2.9 & 58 & 32 & 19 \\
\hline & A II-III & 2 & 6.4 & 13.5 & 3.3 & 4.9 & 44 & 30 & 13 \\
\hline & A II & 1 & 5.0 & 10.6 & 3.2 & 3.9 & 33 & 23 & 8 \\
\hline & A III & 1 & 1.4 & 2.9 & 3.6 & 8.4 & 10 & 7 & 1 \\
\hline \multirow{7}{*}{$\mathrm{FA}_{3}$} & $\mathrm{FBC}_{3}$ & 12 & 45.3 & 100.0 & 0.8 & 0.6 & 100 & 0 & 0 \\
\hline & $>71 \mu \mathrm{m} \mathrm{FBC}_{3}$ & 8 & 24.4 & 53.9 & 1.3 & 1.1 & 90 & 36 & 32 \\
\hline & A I-IV, B II-IV & 7 & 13.9 & 30.8 & 1.9 & 1.6 & 70 & 40 & 28 \\
\hline & A I-III, B II & 4 & 12.4 & 27.4 & 1.8 & 1.2 & 60 & 32 & 19 \\
\hline & A II, B II & 2 & 5.4 & 11.9 & 2.5 & 1.8 & 37 & 25 & 9 \\
\hline & A II & 1 & 1.5 & 3.2 & 4.9 & 3.8 & 19 & 16 & 3 \\
\hline & B II & 1 & 3.9 & 8.6 & 1.7 & 1.1 & 18 & 9 & 2 \\
\hline
\end{tabular}

Table 7 depicts a comparison of the obtained results with the data presented in the literature. The Newton's efficiency of the proposed method and the summarised microsphere recovery are both comparable to the micron separation solution found in the literature. In the case of $\mathrm{FA}_{1}$, the proposed method is slightly advantageous. The scales of the processes significantly differ and the calculated efficiency does not include any losses. However, the fly ash enrichment in the MS for the presented method was satisfactory. The most beneficial was the step with the FB separation. This achieved microsphere recovery at a level of $97-98 \%$, with a $52-55 \%$ reduction in the fly ash mass. Current research confirmed previous observations that the utilization of a combination of classifiers in cenosphere recovery form fly ash is not only favourable, but also necessary to obtain high efficiency with an acceptable level of recovery ratio. 
Table 7. Comparison of the proposed MS recovery methods with the data obtained from the literature.

\begin{tabular}{|c|c|c|c|c|c|c|c|c|}
\hline Source & Device & $\begin{array}{c}\text { Cf, } \\
\text { wt. } \%\end{array}$ & $\begin{array}{r}\text { Cp, } \\
\text { wt. } \%\end{array}$ & $\begin{array}{r}\text { Xp, } \\
\text { wt. } \%\end{array}$ & $\begin{array}{l}\mathbf{R}_{\mathrm{C}} \\
\%\end{array}$ & $\begin{array}{l}\eta, \\
\%\end{array}$ & $\begin{array}{c}\mathrm{R}_{\mathrm{C}} \cdot \eta, \\
\%\end{array}$ & $\begin{array}{c}\text { Process } \\
\text { Scale }\end{array}$ \\
\hline \multirow{2}{*}{$\begin{array}{c}\text { Ando et al. } \\
\text { [39] }\end{array}$} & $45 \mu \mathrm{m}$ sieve & 0.6 & 3.4 & 11.1 & 59 & 49 & 29 & $100 \mathrm{~g}$ \\
\hline & micron separator & 0.3 & 1.7 & 12.2 & 75 & 63 & 47 & $170 \mathrm{~kg} / \mathrm{h}$ \\
\hline $\begin{array}{l}\text { Hirajima } \\
\text { et al. [28] }\end{array}$ & micron separator & 20.0 & 45.5 & 29.0 & 66 & 46 & 30 & $170 \mathrm{~kg} / \mathrm{h}$ \\
\hline \multirow{3}{*}{$\begin{array}{l}\text { Ramme et al. } \\
{[30]}\end{array}$} & $38 \mu \mathrm{m}$ sieve & 0.6 & 1.0 & 35.5 & 59 & 24 & 14 & - \\
\hline & FB column & 1.0 & 5.4 & $5.7^{1}$ & 31 & 25 & 8 & $350 \mathrm{~g}$ \\
\hline & summary & 0.6 & 5.4 & 2.0 & 18 & 16 & 3 & - \\
\hline \multirow{4}{*}{$\begin{array}{l}\text { This work, } \\
\text { FA }_{1}\end{array}$} & FB column & 0.6 & 1.3 & 48.3 & 98 & 50 & 49 & $1000 \mathrm{~g}$ \\
\hline & (71 $\mu \mathrm{m}$ sieve) & 1.3 & 2.0 & $61.5^{1}$ & 94 & 33 & 31 & - \\
\hline & pneumatic separator & 1.3 & 3.1 & $34.3^{1}$ & 83 & 49 & 40 & $2 \mathrm{~g} / \mathrm{min}$ \\
\hline & summary & 0.6 & 3.1 & 16.6 & 81 & 65 & 53 & - \\
\hline \multirow{4}{*}{$\begin{array}{l}\text { This work, } \\
\text { FA }_{2}\end{array}$} & FB column & 0.5 & 1.0 & 47.2 & 97 & 50 & 49 & $1000 \mathrm{~g}$ \\
\hline & (71 $\mu \mathrm{m}$ sieve) & 1.0 & 1.3 & $74.0^{1}$ & 94 & 20 & 19 & - \\
\hline & pneumatic separator & 1.0 & 2.1 & $34.2^{1}$ & 71 & 37 & 26 & $6 \mathrm{~g} / \mathrm{min}$ \\
\hline & summary & 0.5 & 2.1 & 16.1 & 69 & 53 & 36 & - \\
\hline \multirow{4}{*}{$\begin{array}{c}\text { This work, } \\
\text { FA }_{3}\end{array}$} & FB column & 0.4 & 0.8 & 45.3 & 97 & 52 & 50 & $1000 \mathrm{~g}$ \\
\hline & (71 $\mu \mathrm{m}$ sieve) & 0.8 & 1.3 & $53.9^{1}$ & 90 & 36 & 32 & - \\
\hline & pneumatic separator & 0.8 & 1.9 & $30.8^{1}$ & 70 & 40 & 28 & $3 \mathrm{~g} / \mathrm{min}$ \\
\hline & summary & 0.4 & 1.9 & 13.9 & 68 & 54 & 37 & - \\
\hline
\end{tabular}

Figure 5 shows a diagram of the dry method of MS recovery for the $\mathrm{FA}_{1}$ with the water sink-float final step. The diagram includes the sample mass, MS content and the recovery. It can be observed that from $1 \mathrm{~kg}$ of $\mathrm{FA}_{1}$ containing $0.64 \mathrm{wt} . \%$ microspheres, it is possible to recover $5.2 \mathrm{~g}$ of cenospheres. Furthermore, only approx. $17 \mathrm{wt} . \%$ of the fly ash needs to be subjected to wet separation and eventually becomes waste, while the remaining fly ash can be used in industrial applications in its dry form.

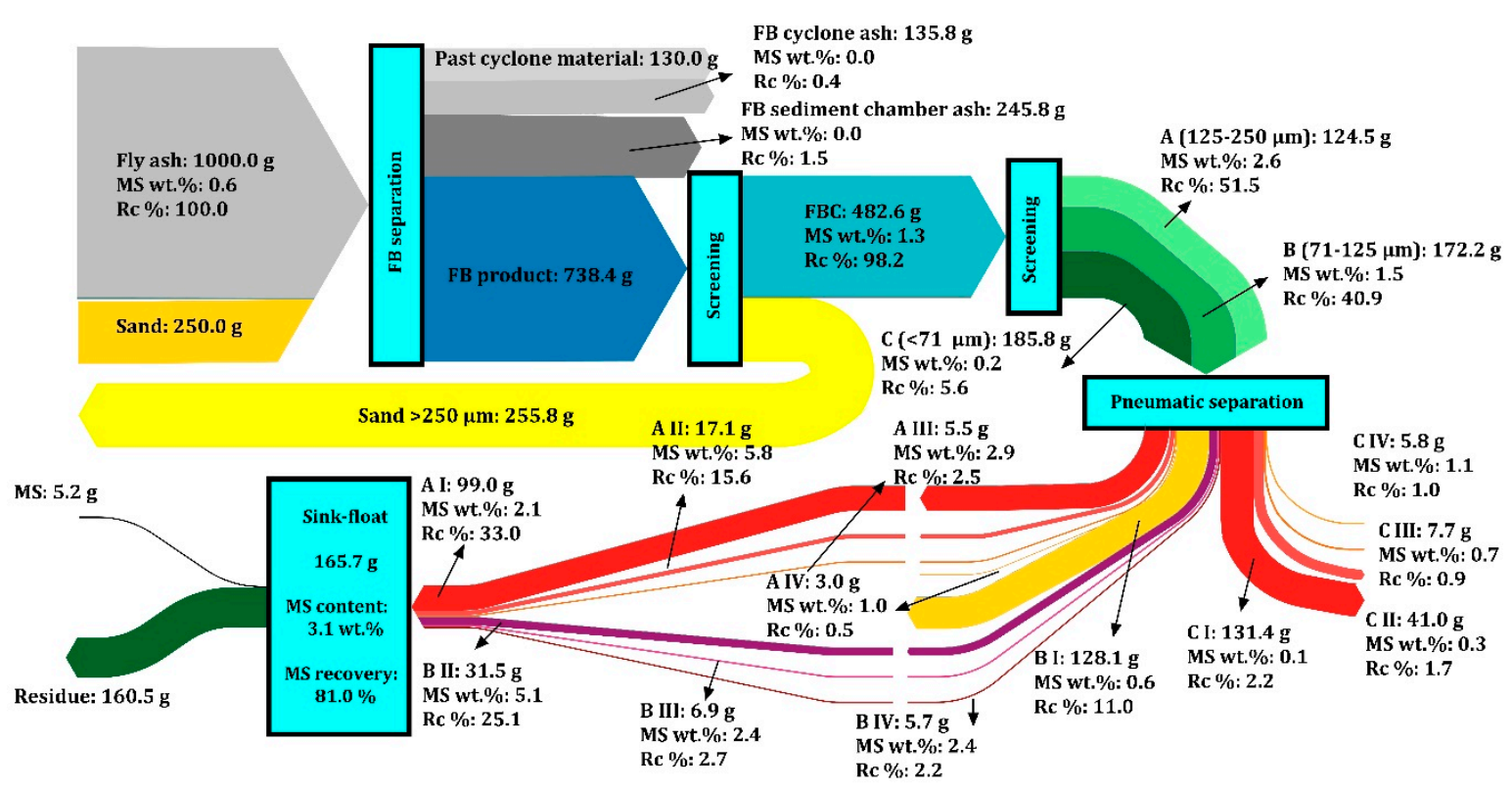

Figure 5. Diagram of the multistage aluminosilicate microspheres recovery from $\mathrm{FA}_{1}$.

For the $\mathrm{FA}_{2}$, the best variant assumes usage of fractions constituting about $16 \mathrm{wt} . \%$ of the initial fly ash and comprising about $2 \mathrm{wt} . \%$ MS with a recovery of around $69 \%$. In the case of the $\mathrm{FA}_{3}$, 
the most valuable material represents approx. $14 \mathrm{wt} . \%$ of the fly ash with $2 \mathrm{wt} . \% \mathrm{MS}$ content and with $68 \%$ recovery.

\section{Conclusions}

The utilization level of fly ash in most countries is low, thus there is a need for its further reprocessing. Fly ash beneficiation is in agreement with the practice of sustainable waste management and leads to the increase in the market value of this industrial waste. The proposed solution allows increasing the economic efficiency of energy generation from coal as well as significantly reducing its impact on the environment.

The dry method of the multistage separation of fly ash enables the recovery of materials that have distinct properties. These materials are fine fly ash particles of different grades of fineness, and the microsphere concentrate. The final cenosphere concentrate can be subjected to further separation or it can also become a source of aluminosilicate microspheres by using the wet method. The residue generated after sink-float is coarse and can be directly added to concrete materials as an aggregate replacement. Furthermore, improved fine S-type fly ash in its dry state can be a desirable addition to high-strength concretes.

The process of fluidised bed separation with use of a mechanical activator proved to be extremely effective in the isolation of ultrafine particles and it could be potentially utilized in the other areas where agglomeration of cohesive particles is an issue. More than $50 \%$ of the fly ash was elutriated from the bed and the resulting coarse fraction still contained more than $97 \%$ of the total cenosphere amount. Further screening steps and pneumatic separation led to as high as $70-80 \%$ recovery ratio of cenospheres with over 50\% Newton's efficiency. A novel arrangement of the gravitational-crossflow zone classifier was designed. Such a solution provides opportunities for the flexible grouping of collected fractions. There is no need for modifications to the construction of the designed device dependently of the characteristics of the material. Unlike the solutions known from the literature, the pneumatic separator presented in the work is simple in construction. There are no rotating parts in this device and no additional power supply is required. This reduces the investment and operating costs of separation, increasing its economic efficiency. The constructed pneumatic separator proved its performance, however some additional validation and optimization is required to improve separation selectivity.

Author Contributions: Conceptualization, methodology, J.W., P.C. and W.Ż.; investigation, data curation, W.Ż. and D.B., writing (original draft), D.B., writing (review and editing), J.W., P.C. and W.Ż. All authors have read and agreed to the published version of the manuscript.

Funding: This research received no external funding.

Conflicts of Interest: The authors declare no conflict of interest.

\section{Abbreviations}

$\begin{array}{ll}\eta & \text { Newton's efficiency } \\ \text { FB } & \text { fluidised bed } \\ \text { FBC } & \text { fluidised bed concentrate } \\ \text { MS } & \text { low density }\left(<1 \mathrm{~g} / \mathrm{cm}^{3}\right) \text { aluminosilicate microspheres (cenospheres) } \\ \text { RC } & \text { recovery of the cenospheres in the coarse-grained fraction (product) } \\ \text { RFA } & \text { recovery of the fly ash in the fine fraction (residue) } \\ \text { Cf } & \text { cenosphere content in the feed } \\ \text { Cp } & \text { cenosphere content in the product } \\ \text { Xp } & \text { the mass content of the product in the feed } \\ \text { FA } & \text { fly ash } \\ \text { A, B, C } & \text { the grain fractions of FBC } \\ \text { I, II, III, IV } & \text { the final fractions of MS concentrates after 3 step separation }\end{array}$




\section{Indices}

1 -material from the first hopper (the first interval)

2-material from the first hopper (the second interval)

3-material from the second hopper (the second interval)

\section{References}

1. Yang, Y.; Guo, X.; Wang, N. Power generation from pulverized coal in China. Energy 2010, 35, 4336-4348. [CrossRef]

2. Bhattacharjee, U.; Kandpal, T.C. Potential of fly ash utilisation in India. Energy 2002, 27, 151-166. [CrossRef]

3. Blissett, R.S.; Rowson, N.A. A review of the multi-component utilisation of coal fly ash. Fuel 2012, 97, 1-23. [CrossRef]

4. Hanif, A.; Lu, Z.; Li, Z. Utilization of fly ash cenosphere as lightweight filler in cement-based composites-A review. Constr. Build. Mater. 2017, 144, 373-384. [CrossRef]

5. Dey, A.; Pandey, K.M. Characterization of fly ash and its reinforcement effect on metal matrix composites: A review. Rev. Adv. Mater. Sci. 2016, 44, 168-181.

6. Zhang, B.; Fan, Z.; Hu, S.; Shen, Z.; Ma, H. Mechanical response of the fly ash cenospheres/polyurethane syntactic foams fabricated through infiltration process. Constr. Build. Mater. 2019, 206, 552-559. [CrossRef]

7. Chauhan, S.R.; Thakur, S. Effects of particle size, particle loading and sliding distance on the friction and wear properties of cenosphere particulate filled vinylester composites. Mater. Des. 2013, 51, 398-408. [CrossRef]

8. Wasekar, P.A.; Kadam, P.G.; Mhaske, S.T. Effect of cenosphere concentration on the mechanical, thermal, rheological and morphological properties of nylon 6. J. Miner. Mater. Charact. Eng. 2012, 11, 807-812. [CrossRef]

9. Rybiński, P.; Żukowski, W.; Bradło, D. Effect of cenospheric fillers on the flammability and fire hazard of silicone rubber composites. J. Therm. Anal. Calorim. 2016, 125, 1373-1386. [CrossRef]

10. Markandeya; Dhiman, N.; Shukla, S.P.; Mohan, D.; Kisku, G.C.; Patnaik, S. Comprehensive remediation study of disperse dyes in wastewater using cenospheres nanosyntactic foam. J. Clean. Prod. 2018, 182, 206-216. [CrossRef]

11. Chandane, V.S.; Rathod, A.P.; Wasewar, K.L.; Sonawane, S.S. Efficient cenosphere supported catalyst for the esterification of n-octanol with acetic acid. C. R. Chim. 2017, 20, 818-826. [CrossRef]

12. Liu, S.; Zhu, J.; Yang, Q.; Xu, P.; Ge, J.; Guo, X. Synthesis and characterization of cube-like Ag@AgCl-doped TiO2/fly ash cenospheres with enhanced visible-light photocatalytic activity. Opt. Mater. 2016, 53, 73-79. [CrossRef]

13. Żukowski, W.; Migas, P.; Bradło, D.; Dulian, P. Synthesis and performance of $\mathrm{TiO}_{2} / \mathrm{fly}$ ash cenospheres as a catalytic film in a novel type of periodic air-sparged photocatalytic reactor. Materials 2020, 13, 13. [CrossRef]

14. Berkowicz, G.; Bradło, D.; Żukowski, W. Cenospheres as an innovative fluidised bed material. Czas. Tech. 2016, 1, 3-10.

15. Żukowski, W.; Berkowicz, G. The combustion of polyolefins in inert and catalytic fluidised beds. J. Clean. Prod. 2019, 236, 13. [CrossRef]

16. Żukowski, W.; Berkowicz, G. The combustion of liquids and low-density solids in a cenospheric fluidised bed. Combust. Flame 2019, 206, 476-489. [CrossRef]

17. Berkowicz, G.; Majka, T.; Zukowski, W. The pyrolysis and combustion of polyoxymethylene in a fluidised bed with the possibility of incorporating $\mathrm{CO}_{2}$. Energy Convers. Manag. 2020, 214, 112888. [CrossRef]

18. Ranjbar, N.; Kuenzel, C. Cenospheres: A review. Fuel 2017, 207, 1-12. [CrossRef]

19. Kiani, A.; Zhou, J.; Galvin, K.P. Enhanced recovery and concentration of positively buoyant cenospheres from negatively buoyant fly ash particles using the inverted reflux classifier. Miner. Eng. 2015, 79, 1-9. [CrossRef]

20. Kiani, A.; Zhou, J.; Galvin, K.P. A pilot scale study of cenosphere recovery and concentration using the inverted reflux classifier. Miner. Eng. 2015, 79, 17-23. [CrossRef]

21. McCarthy, M.J.; Jones, M.R.; Zheng, L.; Robl, T.L.; Groppo, J.G. Characterising long-term wet-stored fly ash following carbon and particle size separation. Fuel 2013, 111, 430-441. [CrossRef]

22. Hirajima, T.; Oosako, Y.; Nonaka, M.; Petrus, H.T.B.M.; Sasaki, K.; Ando, T. Recovery of hollow and spherical particles from coal fly ash by wet separation process. MMIJ 2008, 124, 878-884. [CrossRef] 
23. Manocha, L.M.; Ram, K.A.; Manocha, S.M. Separation of cenospheres from fly ahes by floatation method. Eurasian Chem. Technol. J. 2011, 13, 89-95. [CrossRef]

24. Yoriya, S.; Intana, T.; Tepsri, P. Separation of cenospheres from lignite fly ash using acetone-water mixture. Appl. Sci. 2019, 9, 20. [CrossRef]

25. Vassilev, S.V.; Menendez, R. Phase-mineral and chemical composition of coal fly ashes as a basis for their multicomponent utilization. 4. Characterization of heavy concentrates and improved fly ash residues. Fuel 2005, 84, 973-991. [CrossRef]

26. Acar, İ. Characterization and Utilization of Class F Fly Ashes. Ph.D. Thesis, Middle East Technical University, Ankara, Turkey, 2013.

27. Zyryanov, V.V.; Zyryanov, D.V. Complex processing of pulverized fly ash by dry separation methods. J. Environ. Prot. 2010, 1, 293-301. [CrossRef]

28. Hirajima, T.; Petrus, H.T.B.M.; Oosako, Y.; Nonaka, M.; Sasaki, K.; Ando, T. Recovery of cenospheres from coal fly ash using a dry separation process: Separation estimation and potential application. Int. J. Miner. Process. 2010, 95, 18-24. [CrossRef]

29. Petrus, H.T.B.M.; Hirajima, T.; Oosako, Y.; Nonaka, M.; Sasaki, K.; Ando, T. Performance of dry-separation processes in the recovery of cenospheres from fly ash and their implementation in a recovery unit. Int. J. Miner. Process. 2011, 98, 15-23. [CrossRef]

30. Ramme, B.W.; Noegel, J.J.; Rohatgi, P.K. Separation of Cenospheres from Fly Ash. U.S. Patent 2012/0050519 A1, 1 May 2012.

31. Masuda, H.; Higashitani, K.; Yoshida, H. Powder Technology: Handling and Operations, Process Instrumentation, and Working Hazards, 3rd ed.; CRC Press: Boca Raton, FL, USA, 2006; ISBN 9781420044126.

32. Shapiro, M.; Galperin, V. Air classification of solid particles: A review. Chem. Eng. Process. Process Intensif. 2005, 44, 279-285. [CrossRef]

33. Shabanian, J.; Jafari, R.; Chaouki, J. Fluidization of Ultrafine Powders. Int. Rev. Chem. Eng. 2012, 4, 16-50.

34. Kushnerova, O.A.; Akimochkina, G.V.; Fomenko, E.V.; Rabchevskii, E.V.; Anshits, A.G. Single-Stage Aerodynamic Separation of Fly Ash Produced after Pulverized Combustion of Coal from the Ekibastuz Basin. Solid Fuel Chem. 2018, 52, 188-200. [CrossRef]

35. Suthers, S.P.; Pinto, P.; Nunna, V.; Nguyen, A.V. Experimental study of dry desliming iron ore tailings by air classification. Miner. Process. Extr. Metall. Rev. 2019, 40, 344-355. [CrossRef]

36. Nunna, V.; Hapugoda, S.; Eswarappa, S.G.; Raparla, S.K.; Kumar, R.; Nanda, N.K. Beneficiation of low-grade iron ore fines by using a circulating-type air classifier. Miner. Process. Extr. Metall. Rev. 2019, 40, 356-367. [CrossRef]

37. Sutijan; Sandiwan, S.W.; Saputra, K.I.; Mahdi, M.H.; Albarkan, M.S.; Prasetya, A.; Petrus, H.T.B.M. Effect of inlet speed on gravitational air separator for cenospheres accumulation from fly ash: Modeling using computational fluid dynamics (CFD). In Proceedings of the IOP Conference Series: Materials Science and Engineering, The 2nd Mineral Processing and Technology International Conference, Serpong, Tangerang, Indonesia, 1 November 2018; Volume 478, p. 12.

38. Moghaddam, F.; Sirivivatnanon, V.; Vessalas, K. The effect of fly ash fineness on heat of hydration, microstructure, flow and compressive strength of blended cement pastes. Case Stud. Constr. Mater. 2019, 10, 13. [CrossRef]

39. Ando, T.; Hirajima, T.; Nonaka, M.; Osako, Y. Process for Production of Low-Specific-Gravity Hollow Particles. U.S. Patent 2010/0041620 A1, 15 April 2010.

(C) 2020 by the authors. Licensee MDPI, Basel, Switzerland. This article is an open access article distributed under the terms and conditions of the Creative Commons Attribution (CC BY) license (http://creativecommons.org/licenses/by/4.0/). 